\title{
Digital Ecosystems in the Socio-anthropological Dimension
}

\author{
Tatiana Naumova ${ }^{1 *}$ \\ ${ }^{1}$ Moscow State Technical University of Civil Aviation, Moscow, Russia \\ "Email:naumova_0211@mail.ru
}

\begin{abstract}
The characteristic of the new social structure known as the concept of Society 5.0 in the context of total digitalisation of all spheres of social life is given. The consonance of the Society model 5.0. to the ideas of transhumanism in the views on the formation of the posthuman as a person of the coming digital era, preserving his biological essence and anthropological attributes is revealed. It is shown that the latest digital technologies are designed according to the principle of organisation of natural biological systems, in particular, computer neural networks, evolutionary computing, genetic programming, digital ecosystems simulate neural connections in the biological brain, the biosphere principle of natural selection, chromosomal mutations in living cells, the structure of natural objects, etc. The features of adaptive management as a way of self-organisation of digital ecosystems are formulated: modular structure, compatibility of products and technologies, multi-vector communications, actions of all system participants according to unified protocols. The social and personal risks of digitalisation are highlighted. The prerequisites of the potential problem of the imbalance of artificial and human intelligence from the position of the current ethical norms are outlined. The need for socio-humanitarian diagnostics and ontological examination of the prospects of human compatibility with the new digital reality is substantiated.
\end{abstract}

Keywords: Society 5.0, Transhumanism, Posthuman, Digital ecosystem, Artificial intelligence, Risks of digitalisation.

\section{INTRODUCTION}

The widespread introduction of digital technologies has allowed researchers of various aspects of digitalisation to talk about the formation of global digital space and society's transition to a digital model.

In the course of history, with each change of epochs, the worldview prevailing in society changed. The ancient tradition with its mythological worldview was replaced by the theological paradigm of the Middle Ages, followed by the Renaissance period with anthropocentric views, which was replaced by the rationalism of the Enlightenment and the Modern and Contemporary times enriched the world of human experience with the positivism of the industrial period, and later with postmodern constructivism.
The modern world is going through a digital revolution, which means the end of the postindustrial form of social structure. In the coming digital era, information and communication technologies acquire the status of one of the key components that ensure the functioning of almost all intra-system social connections.

Various aspects of human integration with the artificial information environment are becoming the subject of a broad scientific and public discourse. Gradually, an array of knowledge is forming into independent research areas on the interaction of information, social and natural environments [1].

The human environment undergoes qualitative transformations, while, as in any other anthroposystem in digital systems, the central link remains the person, and the information field remains an obligatory component. This work aims 
to identify the risk-related aspects of the integration of the individual, society with the changing information space. The subject of the analysis is the problem of human compatibility with artificially intelligent systems from a socio-anthropological perspective. The primary methodological approach, which the author of the article is guided by, is to comprehend the nature and ecosystem prerequisites for the construction of information and communication systems of a digital society and to study the foundations of human interaction, as a biological and social construct, with cyberspace.

\section{THE CONCEPT OF SOCIETY 5.0}

In the context of universal digitalisation, the systematisation of the social order, proposed in 2015 as a result of cooperation between the Japanese government and the Keidanren Federation of large Japanese businesses, and called the concept of the society of the future or "Society 5.0", is gaining popularity.

According to the developers, this type of society was preceded by four historical type societies: Society 1.0 - the society of hunters and gatherers, in which the dominant technology was making primitive weapons; Society 2.0 - agrarian society, technology which has been focused on the production of instruments for agriculture; Society 3.0 - industrial society, giving humankind the electricity, the steam engine, industrial technology; Society 4.0 - the information society, which opened the possibility of computer technology. "Society 5.0 is the stage following the information society. It implies a super-intelligent society that uses Big Data in the process of its development [2]".

The new model assumes the consolidation of all resources, total digitalisation and networking, optimisation of social processes through the mutual integration of cybernetic and physical spaces to maximise the use of all available technical, natural and human potential to improve the quality of life. The scientific and technological achievements of a super-intelligent society are not focused on progress, but the well-being of each individual; services are personalised to the needs of a particular subject.

On a planetary scale, the goals of building a "Society 5.0", according to its ideologists, for the next twenty to thirty years are consistent with the Sustainable Development Goals proclaimed by the UN - overcoming global challenges of today, scientific and technological development, harmonised with the interests of each person, social progress, balanced with natural laws. The statement, in our opinion, is controversial. On the one hand, it is declared that the digital economy is a resource-saving economy since it is focused on each specific consumer, which excludes the overproduction of goods and services. Within a single state, perhaps this is the case. However, digital services, stimulating consumer demands, expand the consumer geography and generally contribute to the growth of production volumes, which, ultimately, on a global scale will lead to further aggravation of the fundamental ecological contradiction between the growing material needs of people and the ability of nature to provide them [3]. The integration of all national economies into a single digital economic system, designed on the principles of Society 5.0, still looks like a utopia.

The idea of "Society 5.0" is in many ways consonant with the concepts of transhumanism, around which the fading, then re-escalating disputes have not stopped for half a century. The concept of "transhumanism" was introduced into scientific circulation by the British biologist J. Huxley [4], known not only as of the author of the synthetic theory of evolution but also as the first General Director of UNESCO, as well as one of their organisers of the World Wildlife Fund. For Huxley, transhumanism is a new faith of humanity, combining scientific and technological progress and evolution, as interpreted by Darwinism, in the conditions of the developing world, allowing "a person, continuing to be a person, to surpass himself through the embodiment of new possibilities of his human nature" [5].

\section{POSTHUMAN AS A SOCIAL PROJECT}

Huxley's transhumanism focuses on the idea of permanent human renewal. Modern followers of Huxley overcome natural physical, psychophysiological, cognitive, etc., anthropological limitations are considered in a broader context, arguing about the possibilities of forming a new type of person - a posthuman. It can be stated that the existing interpretations of the concept of "posthuman" interpret it very widely. But in all formulations, the general idea of the continuous improvement of human existence using the latest scientific and technological achievements dominates. The ways and directions of such improvement are fundamentally different. In the context of the topic of this article, we will focus on two opposite but visible approaches.

The first approach considers a person as an object of modernisation. The overcoming the "fundamental limits of physical and mental capabilities set by the limitations of the biological body" [6 ]with the help of bioengineered synthesis 
technologies, including replacing organs with artificial analogues, implanting digital devices into the body, installing neuroadaptive digital communicators in the brain tissues, etc. The most daring projects are planned to create a posthuman with an artificial body. According to S.E. Yurkov, "in place of a biosocial intelligent being, there will be an artificial being imitating a human being" [7, p.153]. But can such a product be considered a person?

The second approach is focused on computerisation, robotisation of the human environment, its external world. Industrial, transport and medical robotics, educational platforms and social networks, integrated security systems, the Internet of Things, intelligent systems of public services and other services dramatically expand the evolutionary limits of the biohuman. The future designers see overcoming human limitations in transplanting artificially set parameters of consciousness to biological beings and even loading mental activity onto a synthetic platform. But as A.L. Nikiforov rightly asserts, "it is completely unclear whether human consciousness can be transferred to another material carrier" $[8, \mathrm{p}$. 90]. Here, the posthuman is seen as the creator of a new nature - a high-tech environment, a person who preserves his biological essence and anthropological attributes and is adapted to the digital social order, feels comfortable in cyberspace and coexists with its inhabitants. Actually, the Society 5.0 project is the embodiment of this idea, but to avoid controversial polemics regarding provisions ambiguously perceived by the scientific community and the general public, it focuses on the indisputable advantages of the new way of life universal comfort and well-being, conditions for self-realisation, opportunities for active participation in the life of society, sustainable economic growth and social development.

\section{NATURAL AND BIOLOGICAL PATTERNS AND DIGITAL REALITY}

The society of the near future is a digital society. A popular global digitalisation trend is developing and implementing complex digital systems integrated into technical, social, economic, transport, and financial systems. It is noteworthy that in the structure of cyberspace, as a reality of a new order, there is an analogy with the reality of the first order - the natural environment. The algorithms of functioning of complex digital systems that are relevant today are neural networks that simulate the work of neural connections in the biological brain, and the very name of which speaks of the ability to demonstrate processes similar to human thinking. When developing modern software products for solving certain classes of problems, socalled evolutionary calculations are used, using the biospheric principle of natural selection, which consists in the fact that the individuals most adapted to these conditions of existence survive and give offspring. As one of the variants of evolutionary calculations, genetic programming is used, simulating the process of chromosomal mutations that fix changes in hereditary traits in the next generations; only individuals are computer programs. In scientific, regulatory and popular literature, such concepts as "ecosystem of scientific communication", "ecosystem of digital services" of a cellular operator or bank, "ecosystem of diversified companies" of the industrial sector of the economy, "ecosystem of the digital economy" of the state began to be used.

The latest digital technologies are designed according to the principle of the organisation of natural biological systems, which once again confirms the reliability of the famous aphorism of the American ecologist B. Commoner "nature knows best" [9]. Today, we can discuss forming a new knowledge stage of ecosystem processes. The previous stage was associated with identifying and studying patterns inherent in natural ecosystems; now, these patterns have been applied to complex systems that unite humans and the digital world.

The change of traditional business models to ecosystem ones has marked one of the defining tasks of the 21st century - improving the efficiency of managing complex, rapidly changing systems. As the main characteristic of such systems, uncertainty actualises the need to develop strategies for managing systems of this class that meet modern requirements. The ecosystem (or adaptive, joint) management approach is considered today as one of the promising directions of self-organisation of complex human-computer systems. The fundamental difference between ecosystem management and other management technologies can be formulated in four main provisions:

- the management of digital ecosystems is built not according to the usual, accepted in management, vertically integrated or hierarchical principle, but the so-called modular. Modularity assumes that individual components or ecosystem services operating independently function as a whole. For example, this format is currently being implemented by leading Russian banks, offering financial services and insurance services, delivery of goods, job search, remote medicine, etc.

- the components united by the ecosystem do not compete but promote each other, even if they belong to more than one industry since they are 
focused not only on their capabilities but also on partners' capabilities. The products and technologies used in the ecosystem are mutually compatible;

- ecosystem participants are connected by interactions that go beyond bilateral; these are multi-vector intersectoral ties, which are characterised by geographical diversity of participants, shorter and more flexible cooperation structures;

- coordination of actions in the ecosystem is regulated by rules, standards, protocols, and processes common to all.

\section{ARTIFICIAL INTELLIGENCE IN THE HUMAN ENVIRONMENT}

Technological innovations of the near future are associated with the use of artificial intelligence AI) - computer systems that exhibit the properties of the mind, for example, searching and generalising information, solving logical and creative tasks, self-learning based on acquired experience, i.e. demonstrating abilities that have always been considered the prerogative of man. The idea of creating such machine systems belonged to the British mathematician Alan Turing and was formulated by him in 1935. Over the past time, three waves have been noted in the development of this technology [10]. Today, AI is able to process the actions of not one person digitally but a group of people and produce a result formed by artificial intelligence. The subject of decision-making is not an individual but a computer.

The use of artificial intelligence is becoming a key factor in the competitiveness of companies and the development of national economies, and therefore a global technological trend, the volume of investments of which amounts to hundreds of millions of dollars annually and is constantly growing $[10,11]$. Today, AI performs complex calculations faster and better, processes large amounts of information, and is stronger than human intelligence in decisions that require the use of logic and intuition, strategic and non-standard thinking. In the future, this imbalance will only increase, which causes concern from the point of view of current ethical standards.

E.V. Seredkina discusses the ability of robotic systems to make moral choices. . The author substantiates "the possibility of a transition from operational morality, according to which the actions of machines are entirely dependent on engineers and consumers, to the so-called functional morality, within which machines will be able to evaluate their actions themselves and respond to a moral challenge [12]". Human interaction with more advanced intelligent systems triggers a complex of new social problems [13]. Obviously, such precedents turn out to be a new experience for a society that requires reflection.

\section{SOCIAL COSTS AND PERSONAL RISKS OF ECOSYSTEM DIGITALISATION}

Among the concerns that are being expressed today about the prospects of humanity due to global digitalisation, several social and personal risks can be identified:

- deformation of the sphere of individual consciousness as a consequence of loss of social skills on the background of digital manipulation of public consciousness;

- levelling of personal identity due to the universal primitivisation, depersonalisation of ethnic, gender, cultural, religious and other differences;

- the destruction of the boundaries of confidential space as a result of the thorough digitisation of personal data and the widespread availability of tracking systems;

- non-compliance with expectations, dissatisfaction with communication due to lack of physical contact and emotional satisfaction;

- reduced motivation to acquire new knowledge and skills, lack of desire to receive education according to established pedagogical technologies;

- changes in mentality due to substituting the real environment with virtual analogues.

Studying the influence of the information society on the development of personal qualities of a person is a relatively new field of scientific research in the context of the COVID-19 pandemic, which is becoming particularly relevant due to the forced social isolation of the individual [14]. The coming digital revolution is not a fundamentally new life practice for humanity. The consequences of social activity throughout history have brought, in addition to the expected effects, also threats to human existence. As M. Heidegger noted back in the fifties of the twentieth century, arguing about the ubiquitous dominance of technology, "man was transplanted into another reality... It's not scary that the world is becoming completely technical; it's much more creepy that a person is not prepared for this change in the world..." [15]. 


\section{CONCLUSIONS}

The pace of evolution of the informatisation of society is many times higher than biological evolution. This means that digital ecosystems will become non-alternative attributes of our environment in the near future. The familiar environment is about to change to a computer, transforming the familiar reality into a digital one.

In scientific studies of socio-anthropological aspects of digitalisation, it has been established that the dynamics of technological updates outstrips the pace of comprehension and scientific interpretation of the changes taking place. However, despite the attractiveness of digital ecosystems, their seeming adaptability under human psycho-physiological peculiarities, such innovations require socialhumanitarian diagnosis, an ontological examination that can detect regularities of functioning of such systems; to understand potential risks and threats to the user; determine anthropological constants, inviolable for all sorts of updates and optimisations to set the imperatives in the selection of future technologies to avoid the destruction of the foundations of human existence. The question of substantiating the anthropological criteria of human compatibility with the global digital space remains open.

\section{REFERENCES}

[1] B.G. Eddy, B. Hearn, J.E. Luther, M. Van Zyll de Jong, W. Bowers, R. Parsons, D. Piercey, G. Strickland, and B. Wheeler, An information ecology approach to science-policy integration in adaptive management of social-ecological systems. Ecology and Society 19(3) (2014) 40. DOI: $\quad$ https://doi.org/10.5751/ES-06752$\underline{190340}$

[2] Uemura Noritsugu, Society 5.0: the view of Mitsubishi Electric, Economic Strategies 19(4) (2017) 122-131.

[3] Tatiana Naumova, Safe Socio-natural Evolution on the Back of Environmental Risks, Proceedings of the International Conference on Contemporary Education, Social Sciences and Ecological Studies (CESSES 2018) 283 (2018) 943-947. DOI: https://doi.org/10.2991/cesses-18.2018.207

[4] Julian Huxley, In New Bottles for New Wine, London: Chatto \& Windus, 1957, 318 p.

[5] Julian Huxley, Transhumanism, Journal of Humanistic Psychology, No. 8(1), pp. 73-76. DOI:

https://doi.org/10.1177/002216786800800107
[6] Manifesto of the strategic social movement "Russia 2045" [Manifest strategicheskogo obshchestvennogo dvizheniya «Rossiya 2045»], 2011. URL: http://www.2045.ru/manifest (accessed: 05.11.2021).

[7] Sergej Yurkov, "Host-man": a new social megaprojects, Tula State University Bulletin, Humanitarian sciences 3 (2016) 155-166.

[8] A.L. Nikiforov, What kind of future is humanity facing? Philosophy Journal 14(3) (2021) 82-95. DOI: https://doi.org/10.21146/2072-0726-2021-143-82-95

[9] Barry Commoner, The Closing Circle: Nature, Man, and Technology, New York, Knopf, 1971.

[10] E.M. Prokhodakov, The current state of artificial intelligence [Sovremennoe sostoyanie iskusstvennogo intellekta], Scientific research [Naukovedcheskie issledovaniya] 2018 (2018) 129-153.

DOI:

https://doi.org/10.31249/scis/2018.00.09

[11] A.A. Porokhovsky, Digitalisation and artificial intelligence: Perspectives and challenges. Ekonomika. Nalogi. Pravo = Economics, taxes \& law 13(2) (2020) 84-91. DOI: https://doi.org/10.26794/1999-849X-2020-132-84-91

[12] Elena Seredkina, Ethical Aspects of social Robotics, Chelovek (The Human Being) 31(4) (2020) 109-127. DOI: https://doi.org/0.31857/S023620070010933-3

[13] O.D. Garanina, T.V. Naumova, The Human Encounter With New Technogenic Threats, European Proceedings of Social and Behavioural Sciences (EpSBS) 80 (2020) 129135.

DOI: https://doi.org/10.15405/epsbs.2020.03.02.16

[14] O. Garanina, N. Al Said, V. Stepenko, M. Troyanskaya, Information society and its impact on personality development, Education and Information Technologies this link is disabled 26(5) (2021) 5457-5475. DOI https://doi.org/10.1007/s10639-021-10549-5

[15] Martin Heidegger, Gelassenheit. Gunther Neske. Pfullingen, 1959, pp. 11-281. 